\title{
Assessing temporal and spatial alterations of flow regimes in the regulated Huai River Basin, China
}

\author{
Yongyong Zhang ${ }^{\mathrm{a}, *}$, Xiaoyan Zhai ${ }^{\mathrm{b}}$, Quanxi Shao ${ }^{\mathrm{c}}$, Ziqi Yan ${ }^{\mathrm{d}}$ \\ ${ }^{a}$ Key Laboratory of Water Cycle and Related Land Surface Processes, Institute of Geographic Sciences and Natural Resources Research, Chinese Academy of Sciences, Beijing \\ 100101, China \\ ${ }^{\mathrm{b}}$ China Institute of Water Resources and Hydropower Research, Beijing 100038; Research Center on Flood and Drought Disaster Reduction of the Ministry of Water Resources, \\ Beijing 100038, China \\ ${ }^{\mathrm{c}}$ CSIRO Digital Productivity, Leeuwin Centre, 65 Brockway Road, Floreat Park, WA 6014, Australia \\ ${ }^{\mathrm{d}}$ State Key Laboratory of Simulation and Regulation of Water Cycle in River Basin, China, Institute of Water Resources and Hydropower Research, Beijing 100038, China
}

\section{A R T I C L E I N F O}

\section{Article history:}

Received 4 May 2015

Received in revised form 30 July 2015

Accepted 1 August 2015

Available online 5 August 2015

This manuscript was handled by Geoff

Syme, Editor-in-Chief

\section{Keywords:}

Flow regime alterations

Flow regime indices

Trend analysis

Classification

Reservoirs and sluices

\begin{abstract}
S U M M A R Y
The assessment of flow regime alterations is fundamental in understanding the potential impact of reservoirs and other water infrastructures on aquatic ecosystems and biota. Previously used methods to classify flow regimes have not captured temporal changes between unregulated and regulated flow regimes at individual stations. In this study, a combination of hierarchical classification and trend analysis was used to assess spatial and temporal flow regime alterations in the Huai River Basin, China. Two categories of flow regime indices were selected to characterize the impacts of reservoir and sluice regulation, including the basic flow indices for mean variation, and the cumulative variation indices for long-term alteration.

The overall impact of reservoirs and sluices on flow regime included the decrease of high flow magnitudes but the increase of low flow magnitudes through time. Moreover, on average, the flow variability, and the high and low flow frequencies were reduced, while their durations were increased. Reservoirs had a greater impact on flow regimes than sluices. The flow regimes at 18 of 30 stations were altered significantly from a pre-regulation condition and were divided into three main types of alteration corresponding to operational rules of reservoirs and sluices. From a management perspective, water projects in China should address the environmental flow requirements of the rivers, particularly in terms of the hydrologic indices affected mostly by reservoirs and sluices. This study will promote the application of flow regime classification and river restoration in highly regulated basins in China.
\end{abstract}

(ㄷ) 2015 Published by Elsevier B.V.

\section{Introduction}

River regulation and fragmentation are prevalent human activities that promote global socioeconomic development through flood control, water supply, and irrigation (World Commission on Dams: WCD, 2000). So far, $60 \%$ of the rivers in the world have been regulated by 6862 registered large reservoirs and millions of small dams (Lehner et al., 2011), and this is projected to reach $70 \%$ by 2025 (Postel, 1998; Zhang et al., 2014). Most of these water projects are located in developing countries, particularly in China, which account for nearly half of water projects in the world (WCD, 2000).

Water project constructions cause significant disturbances to natural river systems (Petts, 1984; Postel and Richter, 2003;

\footnotetext{
* Corresponding author.

E-mail address: zhangyy003@igsnrr.ac.cn (Y. Zhang).
}

Nilsson et al., 2005; Arthington et al., 2010; Arthington, 2012). Water project construction and flow regulation alter the geomorphology of river channels (Graf, 2006), flow discontinuity (Biemans et al., 2011; Costigan and Daniels, 2012), sediment accumulation (Zhang et al., 2012a, 2013a), cause the deterioration of aquatic environments (Ahmet et al., 2006; Chung et al., 2008; Zhang et al., 2010), biodiversity loss, and disturbance to riverine, floodplain and estuarine ecosystems (Bunn and Arthington, 2002; Wu et al., 2003; Poff et al., 2007). Reservoirs and flow regulation are the most prominent causes of environment deterioration and biodiversity loss in freshwater ecosystems of the rivers in the world (Vörösmarty et al., 2010).

The Huai River Basin is the sixth largest river basin, and has the highest density of water projects (reservoirs and sluices) in China, containing nearly $50 \%$ of the water projects in China. The reservoirs and sluices were constructed primarily for socioeconomic benefits, such as flood control, drought relief and power generation. 
However, several environmental issues have emerged since the 1970s, such as rivers drying up, sediment accumulation, frequent occurrences of water pollution incidents, and cancer epidemics in some villages (Zhang et al., 2015). Whether these issues have close relationships with river regulation is one of the urgent questions to be answered in the integrated management of the Huai River Basin, and would be facilitated by a comprehensive assessment of flow change in the basin.

Many studies on flow regime alterations have been conducted to support hydrogeomorphic and environmental responses analysis, environmental flow assessments and river flow management (Arthington, 2012). For the Huai River Basin, Hu et al. (2008) demonstrated the influences of upstream dams on hydrological regime and ecohydrological conditions via the Indicators of Hydrologic Alteration and Range of Variability Approach at Wujiadu Station. Wang and Xia (2010) assessed the impact of 26 reservoirs and 35 sluices on the average annual flow magnitude through a scenario analysis tool based on Soil and Water Assessment Tool (SWAT). Zhang et al. $(2010,2011)$ tested the trend of monthly flow magnitude and quantified the impact of water projects on flow magnitude and water quality in the upper and middle reaches of the Huai River Basin. Zhang et al. (2012b) identified six hydrological classes at 45 stations using hierarchical clustering algorithms as a precursor to environmental flow assessment. However, the impacts of flow regulation were determined by the change of class at each station from unregulated to regulated conditions. These studies demonstrated the broad geographic distribution of flow patterns in the Huai River Basin, and showed that flow regimes have been altered substantially by water infrastructures.

Flow regime classification is to partition flow regimes at large number of gauging stations into relatively homogeneous classes to assess complex patterns of flow regime variation across a broad range of spatial scales (Huang and Ferng, 1990). This approach is widely used to deduce the impact of reservoirs and sluices on flow regimes, as well as the consequences for freshwater ecosystems. The traditional way (Arthington et al., 2006; McManamay et al., 2012; Zhang et al., 2012b and Mackay et al., 2014) was to compare the class change of each station from unregulated to regulated conditions. However, there are limitations with this approach. First, flow alteration by reservoirs and sluices is a long-term and cumulative process, and hydrological classification is not sufficient to detect the changes of flow regime through time. Second, ecologically relevant flow metrics may be considered redundant by statistical approaches such as principal component analysis (PCA) and may therefore be excluded from the classification process (Monk et al., 2007; Mackay et al., 2014). Third, given that the dominant indices that drive classification have changed and caused the differences of flow regime classes in the regulated and unregulated conditions, the comparison of flow regime classifications between these two conditions is subjective. Zhang et al. (2012b) and Mackay et al. (2014) indicated that most index values in the same class were changed in the regulated and unregulated conditions. Thus, the stations owing the same index values might belong to different classes under different conditions. For example, the flow regime class of Huangchuan Station was shifted to another class in Zhang et al. (2012b). However, all the flow indices of this station did not change because it was located in an unregulated headstream. Furthermore, standardization is an essential procedure, to effectively avoid the influence of different units. However, the similar variations of an index (e.g., proportional change or a shift) among all stations by regulation are ignored because of standardization.

The purpose of this study is to explore a procedure of flow regime classification for comprehensively assessing the flow regime alteration in the regulated Huai River Basin in China. Our specific objectives are: (1) to apply trend analysis to determine how individual flow metrics vary through time; (2) to extend the ecologically relevant flow metrics to obtain a better understanding of flow regime alterations; and (3) to cluster individual stations by differences of flow metrics calculated from unregulated and regulated conditions to identify types of flow regime alteration.

\section{Material and methods}

\subsection{Study area}

The Huai River Basin $\left(30^{\circ} 55^{\prime}\right.$ to $36^{\circ} 36^{\prime} \mathrm{N}, 111^{\circ} 55^{\prime}$ to $\left.121^{\circ} 25^{\prime} \mathrm{E}\right)$ is located in eastern China between the Yangtze River Basin and the Yellow River Basin (Fig. 1a). The total drainage area is $270,000 \mathrm{~km}^{2}$ and is divided into Huai River $\left(190,000 \mathrm{~km}^{2}\right)$ and Yishusi River catchments $\left(80,000 \mathrm{~km}^{2}\right)$. The main land uses are dry farmland (62\%) and paddy (20\%), followed by forest, grass, water and urbanisation. The Huai River Basin is not only the most populous basin in China with a population of 206 million in 2012, but also a crucial agricultural production base with grain output of 12.88 million tons in 2012, accounting for $24 \%$ of the total national production.

The Huai River Basin has the highest density of water infrastructure projects in China and suffers from serious water pollution. Over 5700 reservoirs and 5000 sluices have been constructed, with a total storage capacity of 30.3 billion $\mathrm{m}^{3}$, which accounts for $51 \%$ of the annual average runoff in the entire basin. Most rivers are fragmented by reservoirs and sluices. Reservoirs are storages with capacity of greater than 0.1 million $\mathrm{m}^{3}$ and wall height of greater than $15 \mathrm{~m}$, and tend to be located in the headwaters (Fig. 1b). They are mainly designed for water supply, flood control and power generation. Sluices are storages being smaller than reservoirs in capacity and wall height, and tend to be located in the middle and lower catchments (Fig. 1c). They are mainly oriented to interrupt river and attenuate peak flow for flood control (Zhang et al., 2010). Aquatic ecosystems in the basin have deteriorated since the construction of reservoirs and sluices. For example, in 2008 , more than $83 \%$ of the basin's rivers did not reach the national water quality standard (GB3838-2002) and 56\% of the rivers had subhealthy or unhealthy aquatic ecosystem conditions (Xia et al., 2014).

This study focused on upstreams of Bengbu Sluice, which contains most of the reservoirs and sluices in the Huai River Basin. The four main tributaries are the Shaying River, Hongru River and Guo River in the northern part and the collection of rivers in the southern part. Flood and nonflood seasons are from June to September and October to May, respectively.

\subsection{Data sources}

Thirty hydrological stations were selected for flow regime assessment (Table 1), including 12 stations downstream of reservoirs (reservoir-regulated stations), 12 stations downstream of sluices (sluice-regulated stations), and 6 stations located in the downstreams far from the reservoirs and sluices (refer to Fig. 1a) and slightly affected by the regulation of reservoirs and sluices (least regulated stations).

Only the long-term monthly runoff data series from 1961 to 2000 were available from previous studies (Zhang et al., 2012b, 2013b). Runoff data for the Huai River Basin prior to flow regulation were unavailable for most stations. Furthermore, climate change directly affected flow regimes through time (before and after reservoirs and sluices were constructed). Consequently, the unregulated runoff series in the same period was reconstructed under the same climate scenario by the improved SWAT model (the improvement was made by coupling the model with the operational rules of reservoirs and sluices, see Zhang et al., 2013b). The 


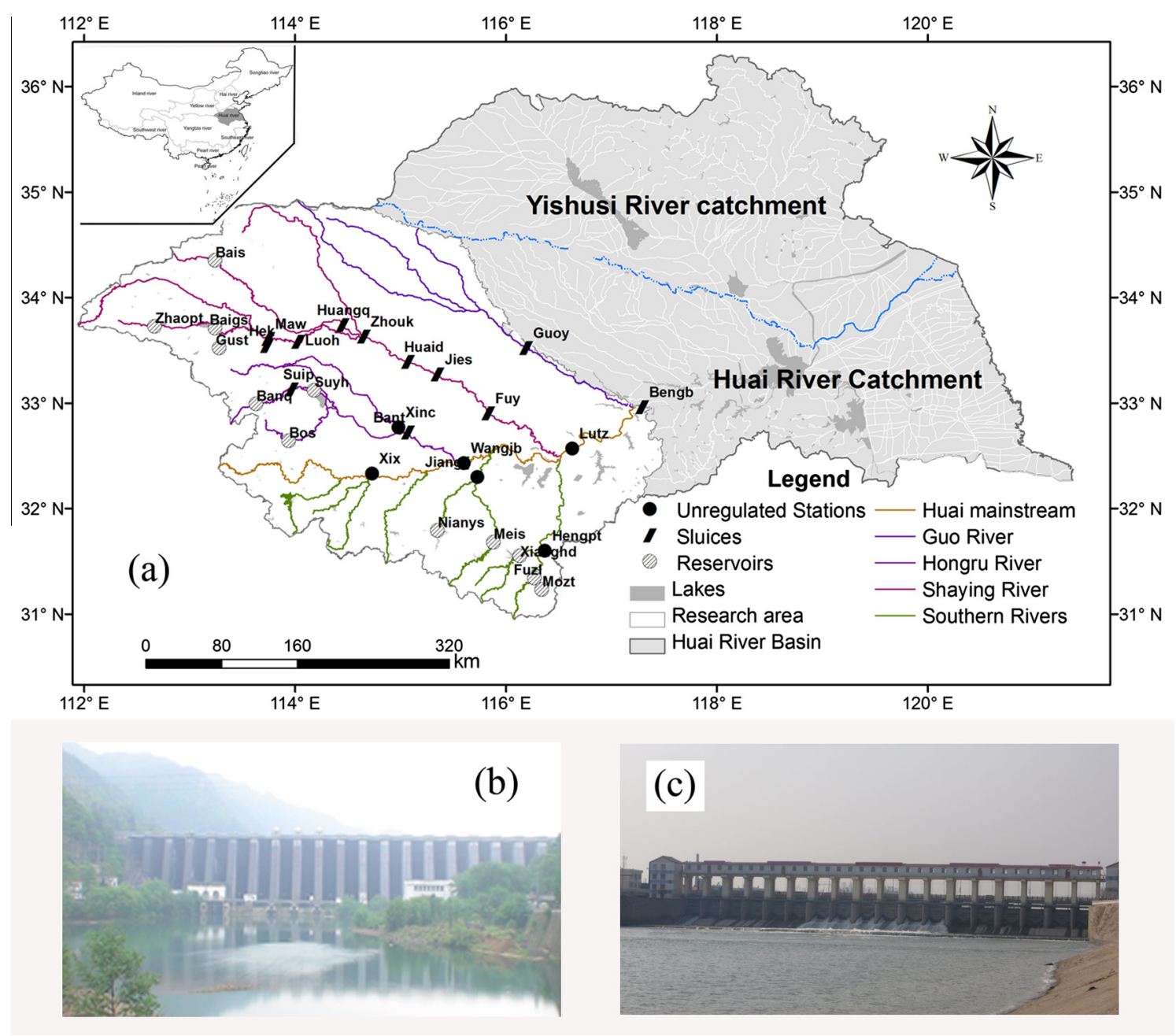

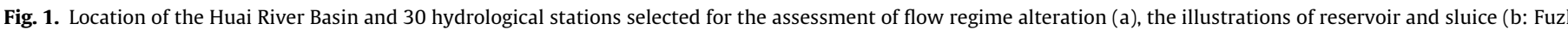
reservoir; c: Huaid sluice).

unregulated runoff series were simulated by setting the reservoirs and sluices fully open in the model. The model improvement and performances on runoff simulations were specified in Zhang et al. (2013b), and the simulated runoff matched well with the observations at monthly scale for most stations.

\subsection{Flow regime indices}

A flow regime is a multivariate assembly of flow characteristics (McManamay et al., 2012). The basic characteristics are magnitude, frequency, duration and timing of particular flow (e.g., floods and dry spells); the variability of overall flow regime, all of which depict the mean variation of flow regimes during a long-term period (Poff et al., 1997; Olden and Poff, 2003). In this study, 58 indices were used to characterize flow regimes, including 25 magnitude indices, 13 variability indices, 8 frequency indices, 7 duration indices and 5 timing indices.

Moreover, flow regime alteration is a cumulative change as the operational rules of reservoirs and sluices usually vary through time, and their completion times are different throughout the basin (Vörösmarty et al., 2010; McManamay et al., 2012, McManamay, 2014; Zhou et al., 2014). The temporal variation of the long-term runoff series should be considered. In this study, the variation through time was characterized by the temporal slope $(S L)$, which is estimated as follows:
$S L=\sum_{i=1}^{n} \sum_{j=i+1}^{n}\left[\frac{1}{n \cdot(n-i)} \cdot \frac{X_{i}-X_{j}}{i-j}\right]$

Hirsch et al. (1982), where $n$ is the length of this index series; $X$ is the flow series. Thirteen SLs were used to describe the flow variations through time, including one for the annual flow series and 12 for the flow series of individual months. The negative value of $S L$ indicates a decreasing change of flow series, while the positive value indicates an increasing change.

In total, 71 indices were used in this study. The description and calculation procedures of all indices were summarized in Table 2. Two sets of index values were calculated for regulated and unregulated regimes, respectively.

\subsection{Statistical analysis}

Three methods were used to assess temporal and spatial variations in flow regimes: (1) For each station, the regulated and unregulated indices were compared to identify those indices which were most influenced by reservoirs and sluices; (2) The seasonal Mann-Kendall (SMK) test was used to assess the temporal changes of flow indices at individual stations through time. (3) For spatial impact assessment, the differences between unregulated and regulated indices were clustered to comprehensively explore the flow characteristic classes and stations that have been altered by 
Table 1

The selected hydrological stations and the attributes of corresponding reservoirs or sluices.

\begin{tabular}{|c|c|c|c|c|c|}
\hline ID & Rivers & $\begin{array}{l}\text { Reservoir- } \\
\text { regulated } \\
\text { stations }\end{array}$ & $\begin{array}{l}\text { Construction } \\
\text { decade }\end{array}$ & $\begin{array}{l}\text { Regulation } \\
\text { capacity (\%) }\end{array}$ & $\begin{array}{l}\text { Catchment } \\
\text { area }\left(\mathrm{km}^{2}\right)\end{array}$ \\
\hline 1 & Hongru & Suyh & $1950 \mathrm{~s}$ & 17.28 & 4498 \\
\hline 2 & Southern & Fuzl & $1950 \mathrm{~s}$ & 21.89 & 1840 \\
\hline 3 & Southern & Mozt & $1950 \mathrm{~s}$ & 33.3 & 570 \\
\hline 4 & Shaying & Zhaopt & $1950 \mathrm{~s}$ & 38.36 & 1430 \\
\hline 5 & Southern & Meis & $1950 \mathrm{~s}$ & 69.3 & 1970 \\
\hline 6 & Shaying & Gust & $1970 \mathrm{~s}$ & 73.31 & 286 \\
\hline 7 & Shaying & Baigs & $1960 \mathrm{~s}$ & 79.65 & 2740 \\
\hline 8 & Shaying & Bais & $1950 \mathrm{~s}$ & 81.56 & 985 \\
\hline 9 & Southern & Nanys & $1970 \mathrm{~s}$ & 87.97 & 924 \\
\hline 10 & Hongru & Bos & $1950 \mathrm{~s}$ & 88.59 & 580 \\
\hline 11 & Southern & Xianghd & $1950 \mathrm{~s}$ & 130.83 & 1476 \\
\hline 12 & Hongru & Banq & $1990 \mathrm{~s}$ & 207.37 & 768 \\
\hline ID & Rivers & $\begin{array}{l}\text { Sluice- } \\
\text { regulated } \\
\text { stations }\end{array}$ & $\begin{array}{l}\text { Construction } \\
\text { decade }\end{array}$ & $\begin{array}{l}\text { Regulation } \\
\text { capacity (\%) }\end{array}$ & $\begin{array}{l}\text { Catchment } \\
\text { area }\left(\mathrm{km}^{2}\right)\end{array}$ \\
\hline 1 & Shaying & Hek & $1970 \mathrm{~s}$ & 0.2 & 2124 \\
\hline 2 & Shaying & Luoh & $1990 \mathrm{~s}$ & 0.26 & 12,150 \\
\hline 3 & Shaying & Maw & $1960 \mathrm{~s}$ & 0.29 & 9448 \\
\hline 4 & Hongru & Bant & $2000 s$ & 0.33 & 11,280 \\
\hline 5 & Hongru & Suip & $2000 \mathrm{~s}$ & 0.58 & 1760 \\
\hline 6 & Huai & Bengb & $1960 \mathrm{~s}$ & 0.89 & 121,330 \\
\hline 7 & Guo & Guoy & $1970 \mathrm{~s}$ & 0.91 & 13,785 \\
\hline 8 & Shaying & Jies & $1970 \mathrm{~s}$ & 1.21 & 29,290 \\
\hline 9 & Shaying & Zhouk & $1970 \mathrm{~s}$ & 1.31 & 25,800 \\
\hline 10 & Shaying & Huaid & $1970 \mathrm{~s}$ & 1.37 & 28,096 \\
\hline 11 & Shaying & Huangq & $1980 \mathrm{~s}$ & 2.01 & 6807 \\
\hline 12 & Shaying & Fuy & $1950 \mathrm{~s}$ & 2.21 & 35,246 \\
\hline ID & Rivers & $\begin{array}{l}\text { Least- } \\
\text { regulated } \\
\text { stations }\end{array}$ & \multicolumn{2}{|c|}{$\begin{array}{l}\text { Distance downstream from } \\
\text { reservoir or sluice }(\mathrm{km})\end{array}$} & $\begin{array}{l}\text { Catchment } \\
\text { area }\left(\mathrm{km}^{2}\right)\end{array}$ \\
\hline 1 & Southern & Hengpt & 41.79 & & 4370 \\
\hline 2 & Southern & Jiangjj & 78.06 & & 5930 \\
\hline 3 & Huai & Lutz & 51.31 & & 88,630 \\
\hline 4 & Huai & Wangjb & 50.1 & & 30,630 \\
\hline 5 & Hongru & Xinc & 105.4 & & 4110 \\
\hline 6 & Huai & Xix & 68.07 & & 10,190 \\
\hline
\end{tabular}

Note: Regulation capacity (RC) as a \% of annual runoff.

reservoirs and sluices. The assessment procedure was shown in Fig. 2, and the specific methods were presented in detail below.

\subsubsection{Single index variation of each station}

The relative change ratio $(R)$ of each flow metric was calculated by comparing the regulated value with the unregulated value. In this study, the change was divided into four categories based on percentiles ( $\pm 20 \%$ increments), i.e., "high" $(R \geqslant 40 \%$ or $R \leqslant-40 \%)$, "moderate" $(20 \% \leqslant R<40 \%$ or $-40 \%<R \leqslant-20 \%)$, "low" $(0<R \leqslant 2$ $0 \%$ or $-20 \% \leqslant R<0)$ and "unchanged" $(R=0)$.

\subsubsection{Temporal impact assessment}

The trend analysis was used to explore the long-term impact of reservoirs and sluices on flow regimes. However, seasonality and temporal autocorrelation usually exist in the long-term series. In this study, the SMK test was applied to detect whether trends existed in regulated and unregulated data sets (Hirsh and Slack, 1984; Helsel and Frans, 2006). Moreover, flow trends at the reservoir-regulated, sluice-regulated and least regulated stations were compared. The commonly used significance level $(\alpha=0.1)$ with the corresponding threshold value of 1.65 was adopted here. If the standardized SMK test statistic $Z$ was greater than 1.65 or less than -1.65 , the existing trend was considered statistically significant. A larger value of slope $(S L)$ indicated a stronger change through time.

\subsubsection{Spatial impact assessment}

The spatial impact assessment of flow regime was conducted by comparing the differences of all the indices at all the 30 stations under the regulated and unregulated conditions. PCA and cluster analysis were employed for hydrological classification. Given that flow indices may be highly correlated, PCA was firstly used to merge correlated indices into independent components. Flow indices were standardized to zero mean and unit standard deviation prior to analysis (Snelder and Biggs, 2002; Zhang et al., 2012b). In general, the cumulative variance more than a certain threshold (80-100\%), indicates that the corresponding components capture sufficient variances of hydrological indices. In this study, the threshold was set at $80 \%$, as recommended by Jolliffe (1972) and Coghlan (2011), and the corresponding resulted components were used in the classification.

To identify the insignificant change class objectively and intuitively, a virtual reference station with differences of 0.0 for all the indices was added into these 30 stations for classification. The class where the virtual reference station was located was determined as the insignificantly impacted class by regulation because the flow regime variations at the stations in this class were similar to the virtual station. The method of Ward (1963) was employed for hierarchical clustering of PCA components. The Goodman-Kruskal index (GKI) (Goodman and Kruskal, 1954), C index (CI) (Hubert and Schultz, 1976), and the cluster size were used to determine the appropriate number of clusters for each analysis. In this study, the most robust clustering was determined by the greatest value of GKI and the lowest value of $C I$. Moreover, all the cluster sizes should not be less than three to ensure the representativeness and integrity of clusters for the assessment of flow regime alteration. Statistical analyses were completed with $\mathrm{R}$ software (version 3.1.1) (R Development Core Team, 2010). The following $\mathrm{R}$ packages were used in the analysis: princomp function in stats package (version 3.1.1) for PCA (R Development Core Team, 2010), hcluster function in amap package (version 0.8-12) for hierarchical clustering (Antoine and Sylvain, 2006) and cluster.stats function in fpc package (version 2.1-9) for cluster performance assessment (Meila, 2007). Moreover, the variation characteristics of different classes were described by some representative flow indices (Snelder et al., 2009).

\section{Results}

\subsection{Overall flow characteristics}

At the reservoir-regulated stations, the change of $\mathrm{MF}_{\mathrm{M}}$ was low during the long-term period, except at Bos (-57.0\%) (Fig. 3). However, the interannual distributions of flows were highly changed, particularly the magnitude of low flow events and in the nonflood season $\left(\mathrm{LM}_{75}, \mathrm{LM}_{90}, \mathrm{LM}_{99}\right.$ and $\left.\mathrm{MF}_{10}-\mathrm{MF}_{05}\right)$. As indicated by $\mathrm{CV}$ indices, the flow variability increased at Bos in the northern part, Meis and Xianghd in the southern part, but decreased at Zhaopt in the northern part and Mozt in the southern part. Moreover, channel drying $\left(\mathrm{LD}_{\mathrm{zr}}\right)$ was increased at Bos in the northern part, Meis and Xianghd in the southern part, but was highly decreased at Baigs, Gust, Suyh and Zhaopt in the northern part, as well as Mozt in the southern part. The flow regimes at five stations in the northern part (Bais, Bos, Gust, Suyh and Zhaopt), and three stations in the southern part (Meis, Mozt and Xianghd) were the highest altered.

At the sluice-regulated stations, the change of $\mathrm{MF}_{\mathrm{M}}$ was also low, except for Hek and Maw. However, flow magnitudes increased in most months of the nonflood season (January, February and October to December), but decreased in August. Low flow magnitudes $\left(\mathrm{LM}_{75}, \mathrm{LM}_{90}\right.$ and $\left.\mathrm{LM}_{99}\right)$ were highly increased, and high flow 
Table 2

The 71 flow regime indices used for flow description in the regulated and unregulated conditions.

\begin{tabular}{|c|c|c|c|c|c|c|}
\hline No. & Groups & $\begin{array}{l}\text { Flow } \\
\text { events }\end{array}$ & Flow regime metrics & Abbreviation & Calculation & Unit \\
\hline 1 & Magnitude & Average & Mean annual flows & $\mathrm{MF}_{\mathrm{M}}$ & $\bar{Q} / A$ & $\mathrm{~mm} /$ year $^{*}$ \\
\hline $2-13$ & & flow & $\begin{array}{l}\text { Mean calendar month flows } \\
\text { from Jan. to Dec. }\end{array}$ & $\mathrm{MF}_{i}(i=01,12)$ & $\bar{Q} i / \bar{Q}$ & none $^{\#}$ \\
\hline $14-16$ & & $\begin{array}{l}\text { Low } \\
\text { flow }\end{array}$ & $\begin{array}{l}\text { Low flow discharge }(75 \mathrm{th} \text {, } \\
\text { 90th, 99th percentile) }\end{array}$ & $\mathrm{LM}_{75}, \mathrm{LM}_{90}, \mathrm{LM}_{99}$ & $\begin{array}{l}\text { 75th, 90th and 99th percentiles, respectively from flow } \\
\text { duration curves }\end{array}$ & none $^{\#}$ \\
\hline $17-19$ & & $\begin{array}{l}\text { High } \\
\text { flow }\end{array}$ & $\begin{array}{l}\text { High flow discharge ( } 1 \text { st, } \\
\text { 10th, 25th percentile) }\end{array}$ & $\mathrm{HM}_{01}, \mathrm{HM}_{10}, \mathrm{HM}_{25}$ & $\begin{array}{l}1 \text { th, } 10 \text { th and } 25 \text { th percentiles, respectively from flow duration } \\
\text { curves }\end{array}$ & none $^{\#}$ \\
\hline $20-22$ & & & $\begin{array}{l}\text { High flow volume }\left(>1 \mathrm{xMF}_{\mathrm{M}} \text {, }\right. \\
\left.3 \mathrm{xMF}_{\mathrm{M}}, 7 \mathrm{xMF}_{\mathrm{M}}\right)\end{array}$ & $\mathrm{H}_{\mathrm{x} 1}, \mathrm{H}_{\mathrm{x} 3}, \mathrm{H}_{\mathrm{x} 7}$ & $\begin{array}{l}\text { High flow volume calculated as the area between the } \\
\text { hydrograph and the upper threshold defined as } 1,3 \text { and } 7 \\
\text { times } \bar{Q} \text {, respectively) }\end{array}$ & none $^{\#}$ \\
\hline $23-25$ & & & $\begin{array}{l}\text { Flood magnitude }(5,10,20- \\
\text { year ARI) }\end{array}$ & $\mathrm{ARI}_{05}, \mathrm{ARI}_{10}, \mathrm{ARI}_{20}$ & $\begin{array}{l}\text { Magnitude of flood events with ARIs of } 5,10 \text { and } 20 \text { years, } \\
\text { respectively }\end{array}$ & none $^{\#}$ \\
\hline 26 & Variability & $\begin{array}{l}\text { Average } \\
\text { flow }\end{array}$ & $\begin{array}{l}\text { Coefficient of variation of } \\
\mathrm{MF}_{\mathrm{M}}\end{array}$ & $\mathrm{CV}_{\mathrm{M}}$ & $\mathrm{CV}$ for annual flows & none \\
\hline $27-38$ & & & $\begin{array}{l}\text { Calendar month CVs from } \\
\text { Jan. to Dec. }\end{array}$ & $\mathrm{CV}_{i}(i=01,12)$ & CV for calendar month flows & none \\
\hline $39-41$ & Frequency & $\begin{array}{l}\text { Low } \\
\text { flow }\end{array}$ & $\begin{array}{l}\text { Low flow spell count }(<75 \text { th, } \\
\text { 90th, 99th percentile) }\end{array}$ & $\mathrm{LF}_{75}, \mathrm{LF}_{90}, \mathrm{LF}_{99}$ & $\begin{array}{l}\text { Mean number of annual occurrences during which the flow } \\
\text { magnitude remains below } \mathrm{LM}_{75}, \mathrm{LM}_{90} \text {, and } \mathrm{LM}_{99} \text {, respectively }\end{array}$ & none \\
\hline $42-44$ & & $\begin{array}{l}\text { High } \\
\text { flow }\end{array}$ & $\begin{array}{l}\text { High flow spell count ( }>1 \text { st, } \\
10 \text { th, } 25 \text { th percentile) }\end{array}$ & $\mathrm{HF}_{01}, \mathrm{HF}_{10}, \mathrm{HF}_{25}$ & $\begin{array}{l}\text { Mean number of annual occurrences during which the flow } \\
\text { magnitude remains above } \mathrm{HM}_{01}, \mathrm{HM}_{10} \text { and } \mathrm{HM}_{25} \text {, respectively }\end{array}$ & none \\
\hline 45,46 & & & $\begin{array}{l}\text { High flow spell count } \\
\left(>3 \mathrm{xMF}_{\mathrm{M}}, 7 \mathrm{xMF}_{\mathrm{M}}\right)\end{array}$ & $\mathrm{HF}_{\mathrm{x} 3}, \mathrm{HF}_{\mathrm{x} 7}$ & $\begin{array}{l}\text { Mean number of annual occurrences during which the flow } \\
\text { magnitude remains above } \mathrm{H}_{\mathrm{x} 3} \text { and } \mathrm{H}_{\mathrm{x} 7} \text {, respectively }\end{array}$ & none \\
\hline $47-49$ & Duration & $\begin{array}{l}\text { Low } \\
\text { flow }\end{array}$ & $\begin{array}{l}\text { Low flow spell duration } \\
(<75 \text { th, 90th, 99th } \\
\text { percentile) }\end{array}$ & $\mathrm{LD}_{75}, \mathrm{LD}_{90}, \mathrm{LD}_{99}$ & $\begin{array}{l}\text { Mean duration of flows which remain below } \mathrm{LM}_{75}, \mathrm{LM}_{90} \text {, and } \\
\mathrm{LM}_{99} \text {, respectively }\end{array}$ & months/year \\
\hline 50 & & & Number of zero-flow month & $\mathrm{LD}_{\mathrm{zr}}$ & Mean annual number of months having zero flow & months/year \\
\hline $51-53$ & & $\begin{array}{l}\text { High } \\
\text { flow }\end{array}$ & $\begin{array}{l}\text { High flow spell duration } \\
\text { (>1st, 10th, 25th percentile) }\end{array}$ & $\mathrm{HD}_{01}, \mathrm{HD}_{10}, \mathrm{HD}_{25}$ & $\begin{array}{l}\text { Mean duration of flows which remain above } \mathrm{HM}_{01}, \mathrm{HM}_{10} \text { and } \\
\mathrm{HM}_{25} \text {, respectively }\end{array}$ & months/year \\
\hline 54 & Timing & Average & Predictability of $\mathrm{MF}_{\mathrm{M}}$ & $\mathrm{P}_{\mathrm{M}}$ & Colwell's (1974) predictability of $\bar{Q}$ & none \\
\hline 55 & & flow & Constancy of $\mathrm{MF}_{\mathrm{M}}$ & $\mathrm{C}_{\mathrm{M}}$ & Colwell's (1974) constancy of $\bar{Q}$ & none \\
\hline 56 & & & Seasonality of $\mathrm{MF}_{\mathrm{M}}$ & $\mathrm{S}_{\mathrm{M}}$ & Colwell's (1974) seasonality of $\bar{Q}$ & none \\
\hline 57 & & $\begin{array}{l}\text { Low } \\
\text { flow }\end{array}$ & $\begin{array}{l}\text { Julian month of annual } \\
\text { minimum }\end{array}$ & $\mathrm{TMn}_{\mathrm{M}}$ & Mean Julian month of the annual minimum flow over all years & month \\
\hline 58 & & $\begin{array}{l}\text { High } \\
\text { flow }\end{array}$ & $\begin{array}{l}\text { Julian month of annual } \\
\text { maximum }\end{array}$ & $\mathrm{TMx}_{\mathrm{M}}$ & Mean Julian month of the annual maximum flow over all years & month \\
\hline 59 & $\begin{array}{l}\text { Temporal } \\
\text { variation }\end{array}$ & $\begin{array}{l}\text { Average } \\
\text { flow }\end{array}$ & $\begin{array}{l}\text { Variation trend of mean } \\
\text { annual flow series }\end{array}$ & $\mathrm{SL}_{\mathrm{M}}$ & Mean slope of annual flow calculated by Eq. (1) & $\mathrm{mm} /$ year \\
\hline $60-71$ & & & $\begin{array}{l}\text { Variation trend of Calendar } \\
\text { month flow series from } \\
\text { January to December. }\end{array}$ & $\mathrm{SL}_{i}(i=01,12)$ & Mean slope of monthly flow calculated by Eq. (1) & $\mathrm{mm} /$ year \\
\hline
\end{tabular}

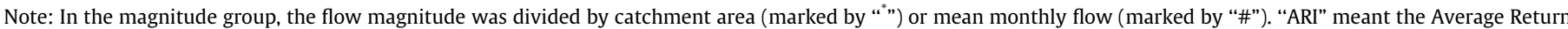

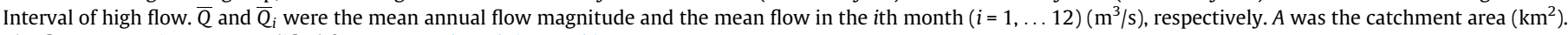
The first 58 metrics were modified from Kennard et al. (2010a,b).

magnitudes $\left(\mathrm{H}_{\mathrm{x} 1}, \mathrm{H}_{\mathrm{x} 3}, \mathrm{H}_{\mathrm{x} 7}, \mathrm{ARI}_{05}, \mathrm{ARI}_{10}\right.$ and $\left.\mathrm{ARI}_{20}\right)$ decreased, particularly $\mathrm{H}_{\mathrm{x} 3}$ and $\mathrm{H}_{\mathrm{x} 7}$. Monthly $\mathrm{CV}$ decreased at most stations, except Maw, Hek, Huangq, Zhouk and Luoh in the upper and middle Shaying River. Moreover, the duration of low flow events was highly varied. For example, $\mathrm{LD}_{75}, \mathrm{LD}_{90}$ and $\mathrm{LD}_{99}$ increased at most stations. However, $\mathrm{LD}_{\mathrm{zr}}$ decreased at Huangq and Jies in the Shaying River, and Guoy in the Guo River, while increased at Zhouk, Maw, Luoh, Huaid and Hek in the Shaying River. The highest alterations of basic flow characteristics were at Huaid, Zhouk, Maw, Jies and Hek in the Shaying River.

Most of flow indices (including flow magnitude, variability, frequency, duration, time and slopes) for least-regulated stations did not differ appreciably between unregulated and regulated conditions. However, high flow magnitudes (particularly $\mathrm{H}_{\mathrm{x} 3}$ and $\mathrm{H}_{\mathrm{x} 7}$ ) and monthly $\mathrm{CV}$ decreased at most stations, except for Xinc in the Hongru River. Thus, the flow regimes at most stations became stable. The frequencies of low and high flows were highly increased at Hengpt in the southern part and Lutz in the Huai River, and the duration of low flows were highly increased at Hengpt and Jiangjj in the southern part, and Lutz in the Huai River. Moreover, as indicated by $\mathrm{LD}_{\mathrm{zr}}$, the channel drying was slightly strengthened at Xinc in the Hongru River, but it did not change at other stations. The highest alterations were at Jiangjj and Hengpt in the southern part.

\subsection{Temporal alteration of flow regimes}

At the reservoir-regulated stations, the results of SMK tests showed that the unregulated monthly flow magnitudes increased significantly (Table 3), which included $\mathrm{SL}_{03}$ at Fuzl, $\mathrm{SL}_{01}$ and $\mathrm{SL}_{03}$ at Mozt, $\mathrm{SL}_{03}$ and $\mathrm{SL}_{06}$ at Nianys in the southern part, $\mathrm{SL}_{06}$ at Zhaopt and $\mathrm{SL}_{07}$ at Bais in the upper Shaying River. Increasing trends appeared before and during the flood season. The greatest slope was $1.27 \mathrm{~mm} /$ year ( $\mathrm{SL}_{06}$ at Nanys). For the regulated flow magnitudes, decreasing trends were detected after the flood season at Zhaopt ( $\mathrm{SL}_{09}$ to $\left.\mathrm{SL}_{11}\right)$ and Xianghd $\left(\mathrm{SL}_{10}, \mathrm{SL}_{11}\right)$ with the greatest slope $0.58 \mathrm{~mm} /$ year ( $\mathrm{SL}_{11}$ at Xianghd). The increasing trends also occurred before or during the flood season, which included $\mathrm{SL}_{06}$ at Zhaopt and Baigs, $\mathrm{SL}_{07}$ to $\mathrm{SL}_{09}$ at Bais, $\mathrm{SL}_{03}$ to $\mathrm{SL}_{06}$ at Gust, $\mathrm{SL}_{05}$ to $\mathrm{SL}_{08}$ at Meis, $\mathrm{SL}_{06}$ and $\mathrm{SL}_{\mathrm{M}}$ at Nianys and $\mathrm{SL}_{05}$ and $\mathrm{SL}_{06}$ at Xianghd. The greatest slope was $3.29 \mathrm{~mm} /$ year $\left(\mathrm{SL}_{\mathrm{M}}\right.$ at Meis). The slopes in the regulated condition were larger than those in the unregulated condition, except at Suyh, Fuzl and Mozt. The directions of trends were different between the regulated and 


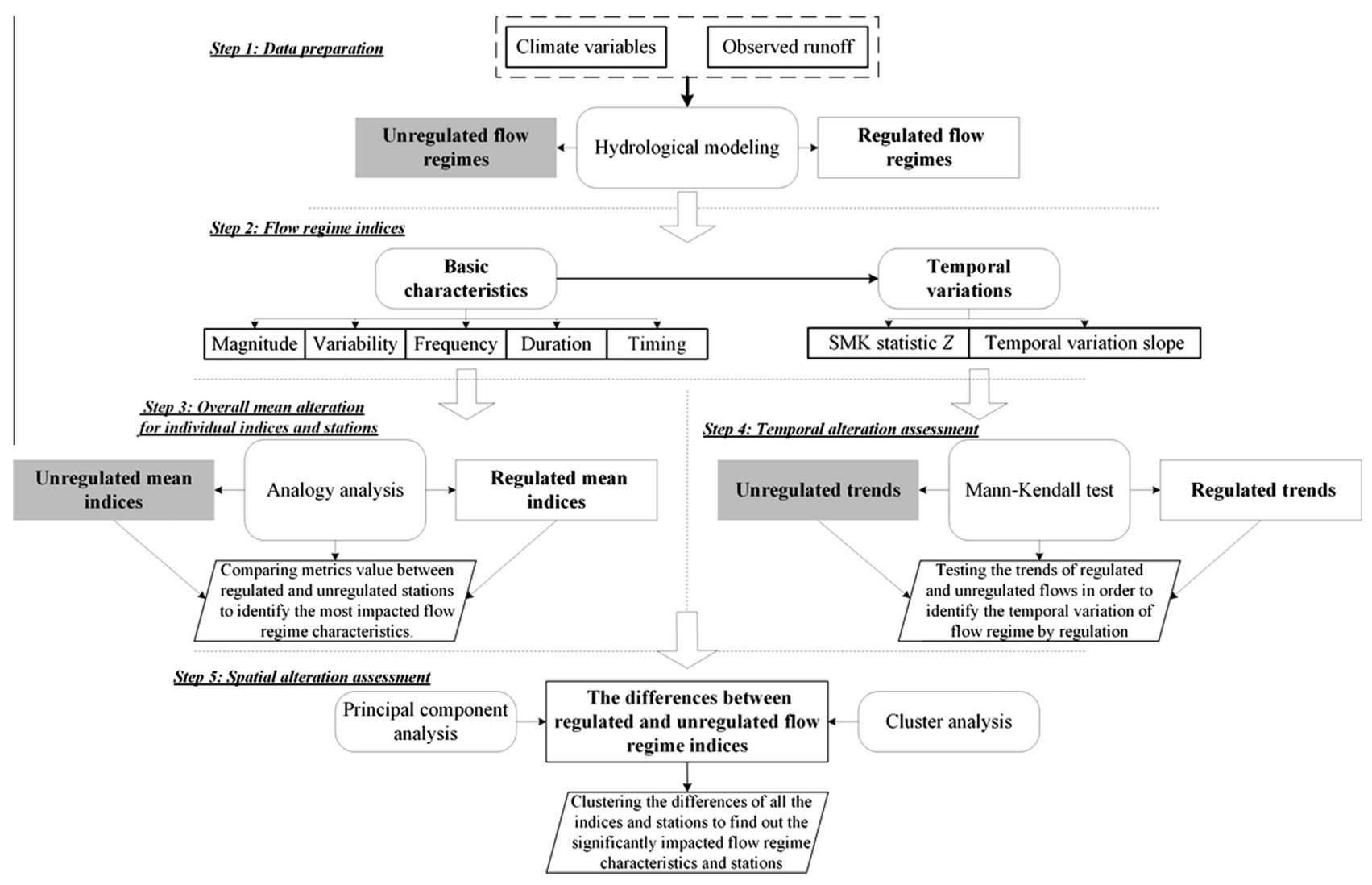

Fig. 2. The comprehensive assessment procedure of flow regime alteration by reservoirs and sluices.

unregulated conditions at nine stations (i.e., Fuzl, Mozt, Meis, Nianys and Xianghd in the southern part and Zhaopt, Gust, Baigs and Bais in the upstream of Shaying River). The temporal slopes were mainly affected in nine months from March to November. Therefore, reservoir regulation induced clear trend differences between the regulated and unregulated flow magnitudes.

At the sluice-regulated stations, the unregulated flow magnitudes showed significantly increasing trends in June (e.g., Luoh, Maw and Zhouk) and significantly decreasing trends in April (e. g., Hek, Suip, Luoh, Zhouk, Jies and Huaid) and November (e.g., Bant). The greatest increasing and decreasing slopes were $0.19 \mathrm{~mm} /$ year $\left(\mathrm{SL}_{06}\right.$ at Luoh) and $-0.36 \mathrm{~mm} /$ year $\left(\mathrm{SL}_{04}\right.$ at Hek), respectively. However, the regulated flow magnitude decreased significantly during the nonflood season in the middle Shaying River (Maw, Luoh, Zhouk and Huangq) and $\mathrm{SL}_{11}$ of Suip in the middle Hongru River. The greatest slope was $-1.22 \mathrm{~mm} /$ year $\left(\mathrm{SL}_{\mathrm{M}}\right.$ at Maw). Only the flow magnitude in June at Hek and Luoh increased significantly, and the greatest slope was $0.62 \mathrm{~mm} / \mathrm{year}$, which appeared at Hek. Nine stations had different trend directions between the regulated and unregulated conditions, namely, Hek, Luoh, Maw, Jies, Zhouk, Huaid and Huangq in the Shaying River, and Suip and Bant in the Hongru River. The temporal slopes were mainly affected in January to March, June, and September to December.

At the least-regulated stations, the trends of unregulated flow magnitude were not statistically significant for most months, except for $\mathrm{SL}_{03}$ at Hengpt, $\mathrm{SL}_{06}$ at Jiangjj in the southern part, $\mathrm{SL}_{11}$ at Wangjb and $\mathrm{SL}_{07}$ and $\mathrm{SL}_{11}$ at $\mathrm{Xix}$ in the Huai River. The greatest decreasing and increasing slopes were $-1 \mathrm{~mm} / \mathrm{year}$, which appeared at Xix, and $0.78 \mathrm{~mm} /$ year, which appeared at Jiangjj, respectively. In the regulated condition, the significant decreasing trends were detected only at Hengpt $\left(\mathrm{SL}_{01}\right)$ and Xix $\left(\mathrm{SL}_{07}\right.$ and $\left.\mathrm{SL}_{11}\right)$, and the significant increasing trends were only observed at Hengpt ( $\mathrm{SL}_{06}$ ) and Jiangjj $\left(\mathrm{SL}_{05}\right.$ and $\mathrm{SL}_{06}$ ). The greatest decreasing and increasing slopes were $-0.88 \mathrm{~mm} / \mathrm{year}$, which appeared at Xix, and $1.24 \mathrm{~mm} /$ year, which appeared at Jiangjj, respectively. However, the trend directions at four stations (i.e., Hengpt and Jiangjj in the southern part, Xix and Wangjb in the Huai River) were different between the regulated and unregulated conditions in five months (January, May to July and December).

\subsection{Spatial alteration of flow regimes}

The differences of 71 flow regime indices between the unregulated and regulated conditions were summarized by PCA into seven components with cumulative variance of $80.2 \%$ (Fig. 4). The first component (accounting for $29.1 \%$ of variances) was related to the differences of magnitudes of low and high flows, and magnitudes in the nonflood season, the high flow frequencies, and CV of monthly flows. The second component (13.8\% of variances) was related to the differences of CV of flows in the nonflood season, the flow timing, and the temporal slopes in the flood season. The third and fourth components $(12.0 \%$ and $9.4 \%$ of variances, respectively) were related to the differences of durations and frequencies of low flow, and high flow, respectively. The fifth and sixth components $(6.2 \%$ and $5.1 \%$ of variances, respectively) were related to the differences of temporal slopes in the nonflood season, while the seventh component (4.7\% of variances) was related to the differences of flow magnitudes in April and August. However, the variances of 10 indices $\left(\mathrm{MF}_{\mathrm{M}}, \mathrm{LF}_{99}, \mathrm{HF}_{01}, \mathrm{LD}_{90}, \mathrm{LD}_{99}\right.$, $\mathrm{HD}_{01}, \mathrm{TMn}_{\mathrm{M}}, \mathrm{TMx}_{\mathrm{M}}, \mathrm{SL}_{10}$ and $\mathrm{SL}_{\mathrm{M}}$ ) were excluded automatically by PCA because these indices did not have a significant loading on any components.

Classifications were evaluated with two to four clusters based on the PCA components (Table 4). The classification result was not affected by the virtual station (Fig. 5). The final classification 


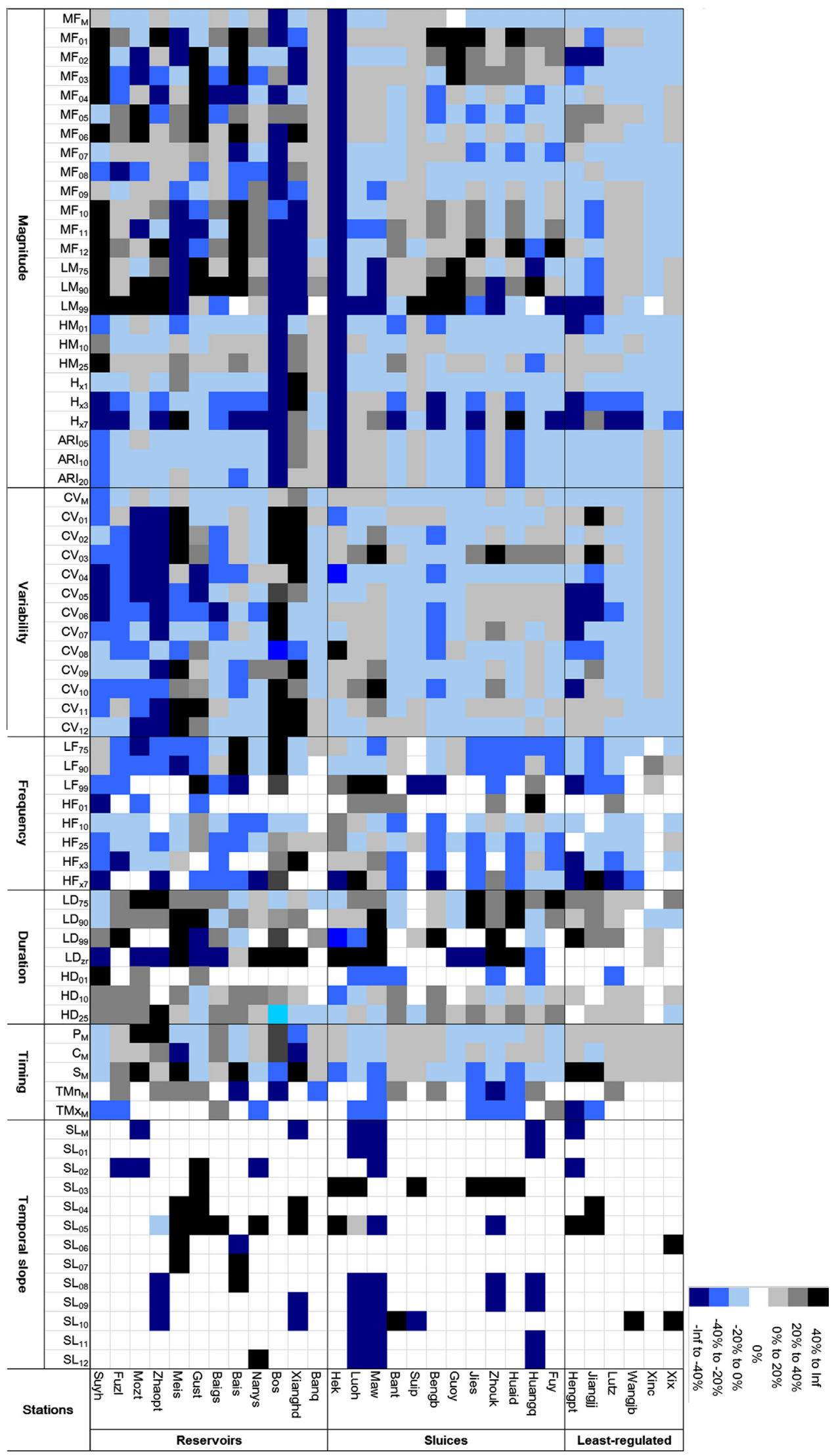

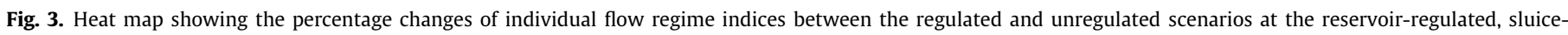
regulated and least regulated stations. 
Table 3

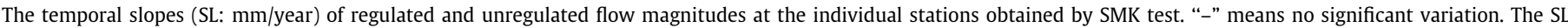
values of regulated and unregulated flow magnitudes were shown outside and inside the parentheses, respectively.

\begin{tabular}{|c|c|c|c|c|c|c|c|c|c|c|c|c|c|}
\hline Station & Jan. & Feb. & Mar. & Apr. & May & Jun. & Jul. & Aug. & Sept. & Oct. & Nov. & Dec. & Annual \\
\hline \multicolumn{14}{|c|}{ Reservoir-regulated stations } \\
\hline Fuzl & $-(-)$ & $-(-)$ & $-(0.65)$ & $-(-)$ & $-(-)$ & $-(-)$ & $-(-)$ & $-(-)$ & $-(-)$ & $-(-)$ & $-(-)$ & $-(-)$ & $-(-)$ \\
\hline Mozt & $-(0.57)$ & $-(-)$ & $-(0.89)$ & $-(-)$ & $-(-)$ & $-(-)$ & $-(-)$ & $-(-)$ & $-(-)$ & $-(-)$ & $-(-)$ & $-(-)$ & $-(-)$ \\
\hline Zhaopt & $-(-)$ & $-(-)$ & $-(-)$ & $-(-)$ & $-(-)$ & $0.33(0.4)$ & $-(-)$ & $-(-)$ & $-0.37(-)$ & $-0.51(-)$ & $-0.07(-)$ & $-(-)$ & $-(-)$ \\
\hline Meis & $-(-)$ & $-(-)$ & $-(-)$ & $-(-)$ & $2.19(-)$ & $1.53(-)$ & $1.67(-)$ & $1.35(-)$ & $-(-)$ & $-(-)$ & $-(-)$ & $-(-)$ & $-(-)$ \\
\hline Gust & $-(-)$ & $-(-)$ & $0.1(-)$ & $0.09(-)$ & $0.76(-)$ & $0.31(-)$ & $-(-)$ & $-(-)$ & $-(-)$ & $-(-)$ & $-(-)$ & $-(-)$ & $-(-)$ \\
\hline Baigs & $-(-)$ & $-(-)$ & $-(-)$ & $-(-)$ & $-(-)$ & $0.2(-)$ & $-(-)$ & $-(-)$ & $-(-)$ & $-(-)$ & $-(-)$ & $-(-)$ & $-(-)$ \\
\hline Bais & $-(-)$ & $-(-)$ & $-(-)$ & $-(-)$ & $-(-)$ & $-(-)$ & $0.02(0.05)$ & $0.08(-)$ & $0.12(-)$ & $-(-)$ & $-(-)$ & $-(-)$ & $-(-)$ \\
\hline Nanys & $-(-)$ & $-(-)$ & $-(0.35)$ & $-(-)$ & $-(-)$ & $2(1.27)$ & $-(-)$ & $-(-)$ & $-(-)$ & $-(-)$ & $-(-)$ & $-(-)$ & $3.29(-)$ \\
\hline Xianghd & $-(-)$ & $-(-)$ & $-(-)$ & $-(-)$ & $1.49(-)$ & $1.75(-)$ & $-(-)$ & $-(-)$ & $-(-)$ & $-0.48(-)$ & $-0.58(-)$ & $-(-)$ & $-(-)$ \\
\hline \multicolumn{14}{|c|}{ Sluice-regulated stations } \\
\hline Hek & $-(-)$ & $-(-)$ & $-(-)$ & $-(-0.36)$ & $-(-)$ & $0.62(-)$ & $-(-)$ & $-(-)$ & $-(-)$ & $-(-)$ & $-(-)$ & $-(-)$ & $-(-)$ \\
\hline Luoh & $-0.08(-)$ & $-0.09(-)$ & $-(-)$ & $-(-0.08)$ & $-(-)$ & $0.19(0.19)$ & $-(-)$ & $-(-)$ & $-0.39(-)$ & $-0.31(-)$ & $-0.23(-)$ & $-0.13(-)$ & $-1.15(-)$ \\
\hline Maw & $-0.09(-)$ & $-0.06(-)$ & $-0.04(-)$ & $-(-)$ & $-(-)$ & $-(0.1)$ & $-(-)$ & $-(-)$ & $-0.42(-)$ & $-0.38(-)$ & $-0.25(-)$ & $-0.13(-)$ & $-1.22(-)$ \\
\hline Bant & $-(-)$ & $-(-)$ & $-(-)$ & $-(-)$ & $-(-)$ & $-(-)$ & $-(-)$ & $-(-)$ & $-(-)$ & $-(-0.01)$ & $-(-)$ & $-(-)$ & $-(-)$ \\
\hline Suip & $-(-)$ & $-(-)$ & $-(-)$ & $-(-0.1)$ & $-(-)$ & $-(-)$ & $-(-)$ & $-(-)$ & $-(-)$ & $-(-)$ & $-0.08(-)$ & $-(-)$ & $-(-)$ \\
\hline Jies & $-(-)$ & $-(-)$ & $-(-)$ & $-(-0.04)$ & $-(-)$ & $-(-)$ & $-(-)$ & $-(-)$ & $-(-)$ & $-(-)$ & $-(-)$ & $-(-)$ & $-(-)$ \\
\hline Zhouk & $-(-)$ & $-(-)$ & $-(-)$ & $-(-0.05)$ & $-(-)$ & $-(0.1)$ & $-(-)$ & $-(-)$ & $-0.2(-)$ & $-0.18(-)$ & $-(-)$ & $-(-)$ & $-(-)$ \\
\hline Huaid & $-(-)$ & $-(-)$ & $-(-)$ & $-(-0.04)$ & $-(-)$ & $-(-)$ & $-(-)$ & $-(-)$ & $-(-)$ & $-(-)$ & $-(-)$ & $-(-)$ & $-(-)$ \\
\hline Huangq & $-0.02(-)$ & $-0.01(-0.01)$ & $-(-)$ & $-(-)$ & $-(-)$ & $-(-)$ & $-(-)$ & $-(-)$ & $-0.05(-)$ & $-0.06(-)$ & $-(-)$ & $-0.02(-)$ & $-0.1(-)$ \\
\hline \multicolumn{14}{|c|}{ Less-regulated stations } \\
\hline Hengpt & $-0.39(-)$ & $-(-)$ & $-(0.49)$ & $-(-)$ & $-(-)$ & $0.9(-)$ & $-(-)$ & $-(-)$ & $-(-)$ & $-(-)$ & $-(-)$ & $-(-)$ & $-(-)$ \\
\hline Jiangjj & $-(-)$ & $-(-)$ & $-(-)$ & $-(-)$ & $0.95(-)$ & $1.24(0.78)$ & $-(-)$ & $-(-)$ & $-(-)$ & $-(-)$ & $-(-)$ & $-(-)$ & $-(-)$ \\
\hline Wangjb & $-(-)$ & $-(-)$ & $-(-)$ & $-(-)$ & $-(-)$ & $-(-)$ & $-(-)$ & $-(-)$ & $-(-)$ & $-(-)$ & $-(-0.25)$ & $-(-)$ & $-(-)$ \\
\hline Xix & $-(-)$ & $-(-)$ & $-(-)$ & $-(-)$ & $-(-)$ & $-(-)$ & $-0.88(-1)$ & $-(-)$ & $-(-)$ & $-(-)$ & $-(-0.23)$ & $-0.12(-)$ & $-(-)$ \\
\hline
\end{tabular}

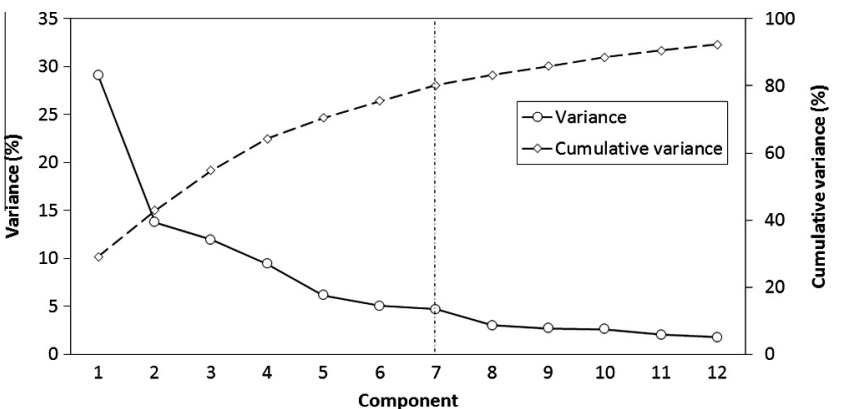

Fig. 4. The scree plot of variances of individual PCA components and their cumulative variances.

had four clusters with the greatest value of $C K I(0.61)$ and the least value of $C I(0.14)$.

Thirteen stations belonged to Class 1, namely, three reservoirregulated stations (Zhaopt, Baigs and Banq), five sluice-regulated stations (Huangq, Suip, Bant, Guoy and Bengb), four least regulated stations (Xinc, Xix, Wangjb and Lutz) and the reference station. These stations were distributed in the upper Shaying River (three stations), Hongru River (four stations), Guo River (one station) and Huai Mainstream (four stations) (Fig. 6). Although some indices of these stations were changed (e.g., temporal slopes and high flow magnitudes), the differences of most indices were close to 0.0 (Fig. 7). Thus, flow regulation did not significantly change the overall flow regime characteristics. This class was named as Late Summer Flow with No Significant Variation (Late Summer Flow: NS) (Table 5 and Fig. 8a).

Table 4

The four indices used to evaluate the flow classification. Bold text shows the optimal number of clusters.

\begin{tabular}{llll}
\hline Class Numbers & GKI & CI & Class size \\
\hline 2 & 0.04 & 0.46 & 13,18 \\
3 & 0.34 & 0.34 & $13,7,11$ \\
$\mathbf{4}$ & $\mathbf{0 . 6 1}$ & $\mathbf{0 . 2 0}$ & $\mathbf{1 3 , 7 , 6 , 5}$ \\
\hline
\end{tabular}

In Class 2, six stations were located in the southern part (four reservoir stations and two least regulated stations) (Fig. 6). The difference of $\mathrm{MF}_{\mathrm{M}}$ was $-0.00043 \mathrm{~mm} /$ year, and the flow magnitudes increased in the late spring and early summer, but decreased in the other months (Fig. 7). The obvious difference appeared in June (0.04487). Thus, the flow magnitudes were further increased by the regulation in the flood season, but decreased in the nonflood season. Flow regimes became more variable, particularly in late spring and summer. The flow frequencies of low and high flows decreased while their durations increased. Thus, channel drying was increased, and $\mathrm{LD}_{\mathrm{zr}}$ increased from 0.022 to 0.066 month/year. Moreover, the differences of $\mathrm{TMn}_{\mathrm{M}}$ and $\mathrm{TMx}_{\mathrm{M}}$ were positive and negative, respectively, which indicated that the occurrence time was delayed for the minimum flow, but advanced for the maximum flow by the regulation. For the temporal variation trends, the long-term impact of regulation caused the increase of flow in late spring and early summer and the decrease of flow in the other months. Thus, flow gradually increased in summer, and the variation was named as Middle Summer Flow with Less Magnitude, More Variability, and More Intermittency by Regulation (Middle Summer Flow: L-V-I) (Table 5 and Fig. 8b).

Seven stations belonged to Class 3, including six sluiceregulated stations in the middle Shaying River and one reservoirregulated station in the upper southern part (Fig. 6). The regulation did not obviously change the magnitude of average flow, high and low flows, and average flow variability. However, it changed the distribution of flow magnitudes and variability in the calendar months (Fig. 7). In particular, the flow magnitude decreased obviously in the summer, but increased slightly in autumn and winter. Flow variability increased in spring, summer and autumn, but decreased in winter. The most obvious differences of magnitudes and variability were $0.03\left(\mathrm{MF}_{07}\right)$ and $0.26\left(\mathrm{CV}_{03}\right)$, respectively. The frequencies of both low and high flows decreased, but their durations increased. Channel drying was distinctly aggravated, and $\mathrm{LD}_{\mathrm{zr}}$ increased from 0.011 to 0.301 month/year. Moreover, the differences of both $\mathrm{TMn}_{\mathrm{M}}$ and $\mathrm{TMx}_{\mathrm{M}}$ were negative, which indicated that the occurrence times of the minimum and maximum flows were advanced by the regulation. For the temporal variation 

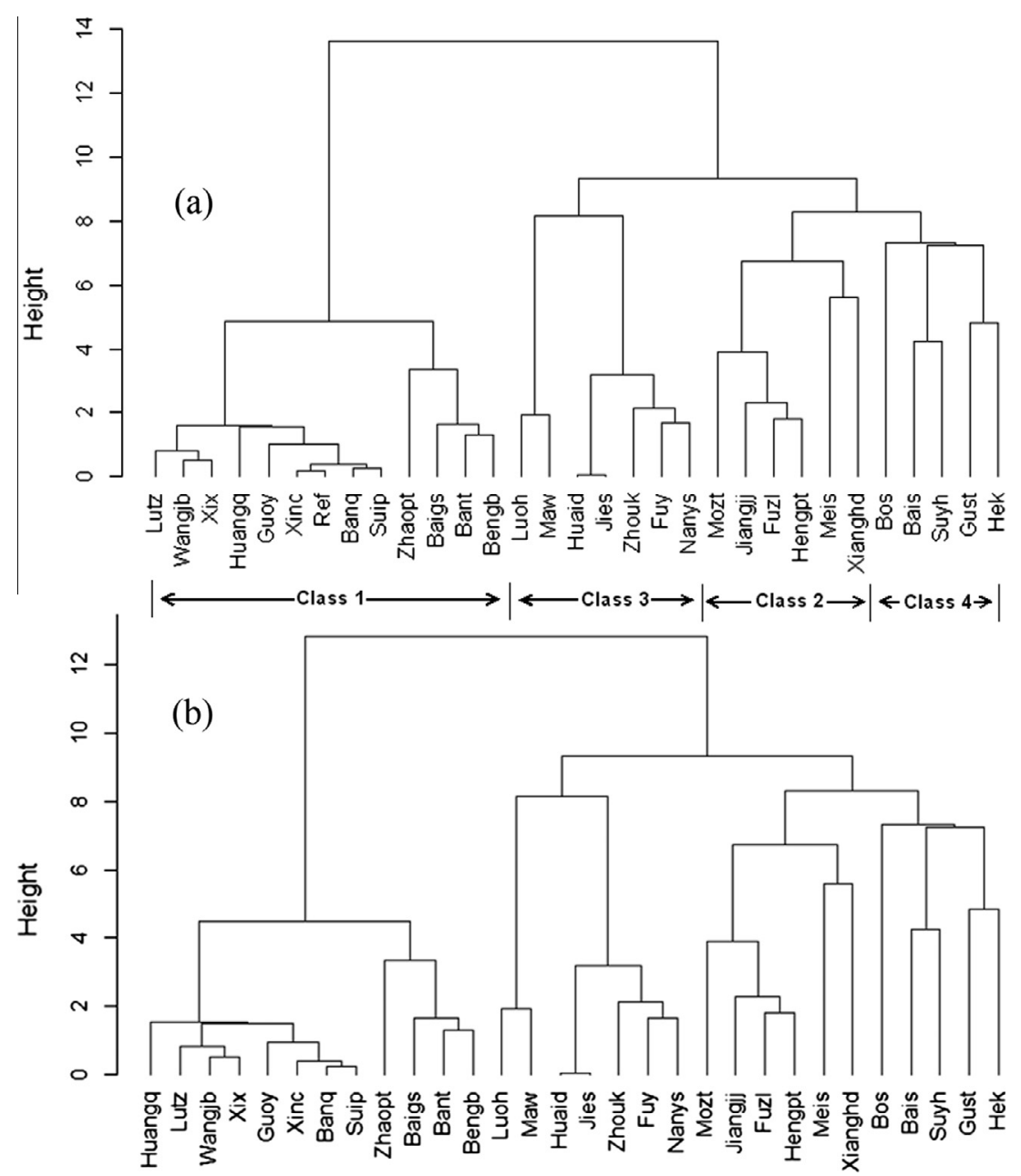

Fig. 5. The hierarchical diagrams for flow variation classifications by cluster analysis (a: 30 stations and one reference station; b: 30 stations).

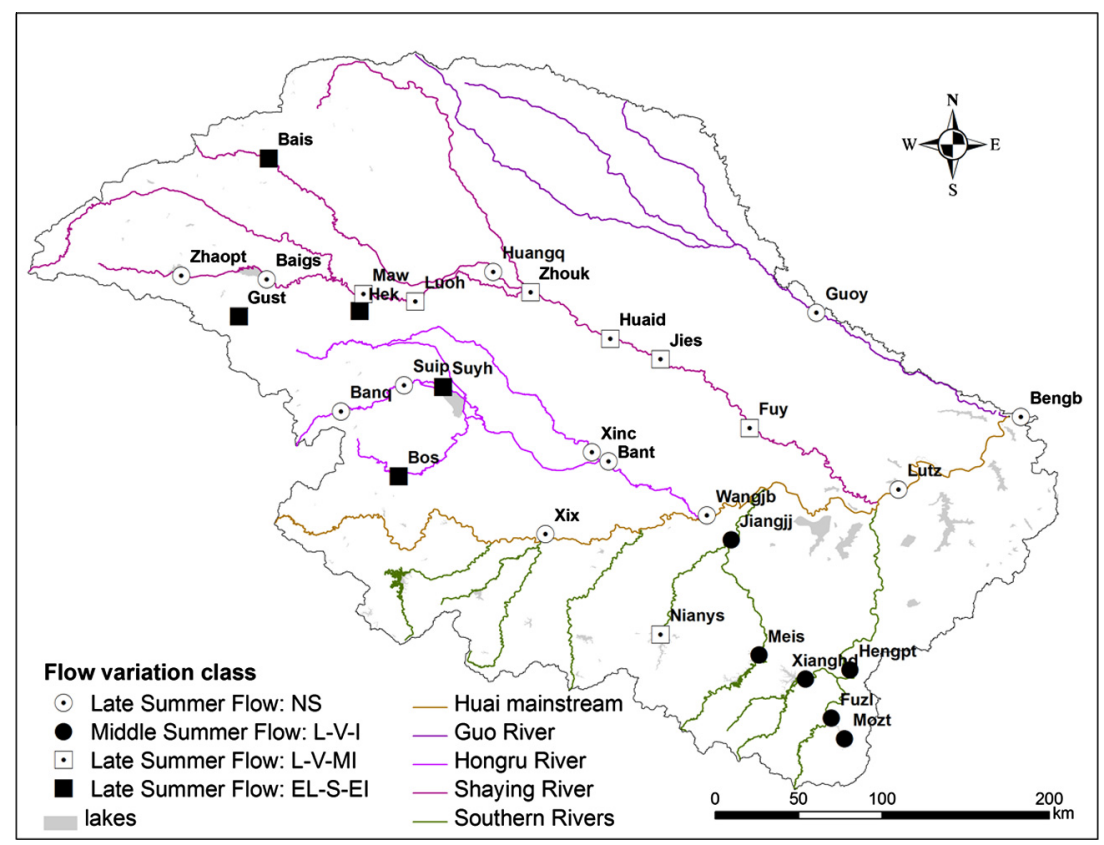

Fig. 6. Geographical locations of 30 stations grouped into four flow variation classes by cluster analysis. 

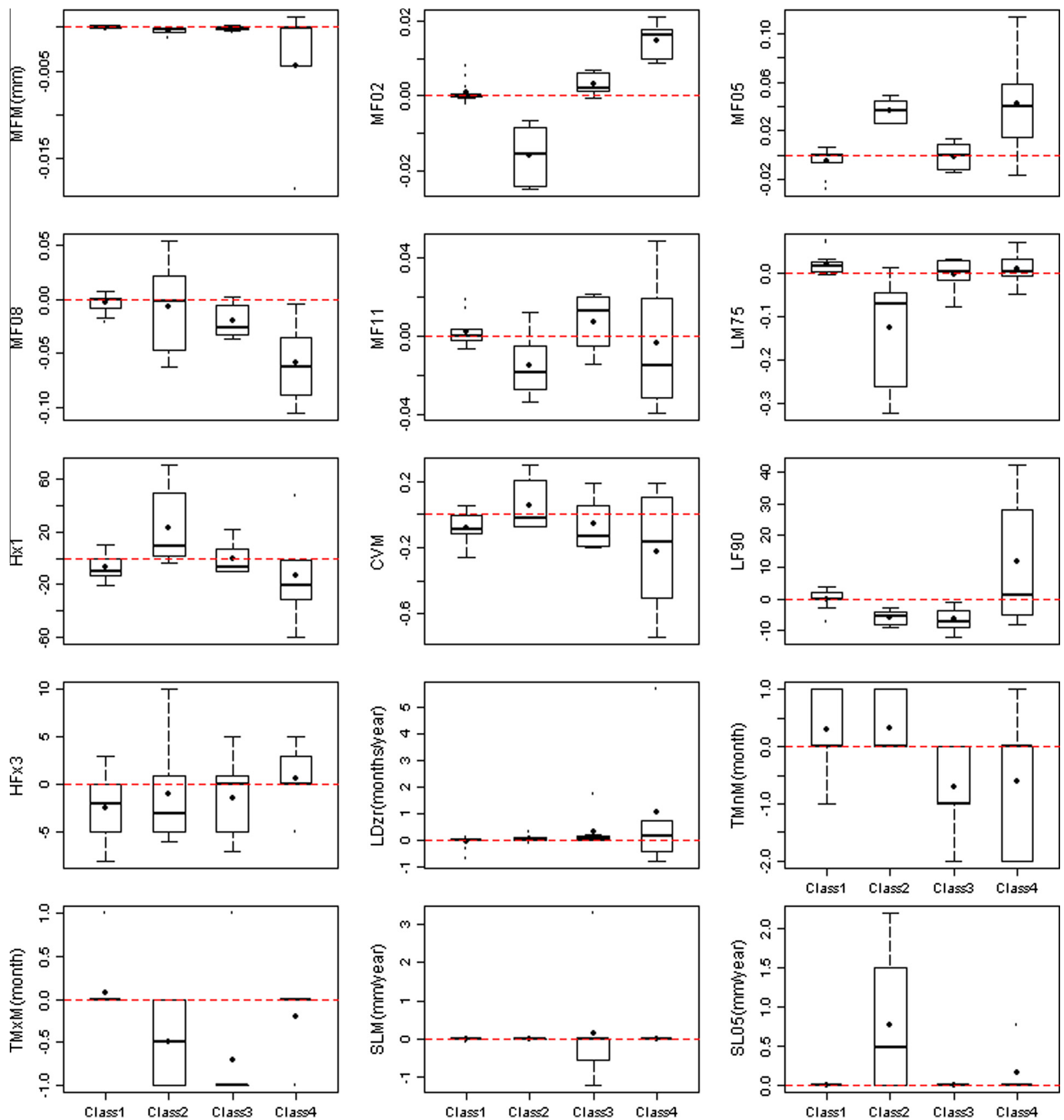

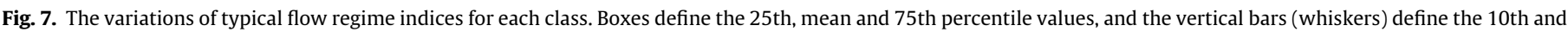
90th percentile values. Median values and outliers are defined by the black solid dot and hollow dot symbol, respectively.

trend, the long-term impact of regulation was detected as increasing flow in April and June and decreasing flow in autumn and winter. Thus, flow gradually decreased in the autumn and winter, and the variation was named as Late Summer Flow with Less Magnitude, More Variability, and Much More Intermittency by regulation (Late Summer Flow: L-V-MI) (Table 5 and Fig. 8c).

Five stations belonged to Class 4 including four reservoirregulated stations and one sluice-regulated station. These stations were located in the tributaries of the upper Shaying River and the Hongru River (Fig. 6). The index differences were greater than those in other classes, particularly the flow magnitudes of flood season and high flow, flow variability, frequency and duration of low flow and zero-flow months (e.g. $\mathrm{MF}_{\mathrm{M}}=-0.00439 \mathrm{~mm}$, $\mathrm{MF}_{08}=-0.059, \quad \mathrm{CV}_{\mathrm{M}}=0.22, \quad \mathrm{H}_{\mathrm{x} 3}=-26.76, \quad \mathrm{LF}_{90}=11.60$ and $\mathrm{LD}_{\mathrm{zr}}=1.07$ months/year) (Fig. 7). The differences of flow magnitudes were negative in the flood season, but positive in other months. This finding was attributed to more significant decrease of the regulated flow than the unregulated flow in most months, except in July. The CV of monthly flows decreased in spring and autumn with the average amplitude of -0.157 , and increased in summer and winter with the average amplitude of 0.078 . However, the CV at the annual scale decreased with the amplitude of -0.224 . Thus, flow regimes became stable, particularly in spring and autumn, but variable in summer and winter. Frequency differences of low flows were positive, whereas the differences of high flows were negative. The duration differences were no less than 0.0 , particularly $\mathrm{LD}_{\mathrm{zr}}$ (1.07 months/year). For the flow timing, $\mathrm{TMn}_{\mathrm{M}}$ and $\mathrm{TMx}_{\mathrm{M}}$ were obviously advanced. The long-term impacts of regulation mainly manifested that flow increased in the spring, June and autumn, but decreased in July. Thus, flow gradually 
Table 5

The main characteristics of flow variation classes identified by classification of flow regime differences between the unregulated and regulated conditions.

\begin{tabular}{|c|c|c|c|c|c|}
\hline Characteristic & $\begin{array}{l}\text { Flow } \\
\text { events }\end{array}$ & $\begin{array}{l}\text { Class } \\
1\end{array}$ & Class 2 & Class 3 & Class 4 \\
\hline \multirow[t]{2}{*}{ Magnitude } & $\begin{array}{l}\text { Average } \\
\text { flow }\end{array}$ & - & Decrease & - & Extremely decrease \\
\hline & $\begin{array}{l}\text { Monthly } \\
\text { distribution }\end{array}$ & - & $\begin{array}{l}\text { Increase in late spring and early summer; } \\
\text { decrease in the other months }\end{array}$ & $\begin{array}{l}\text { Decrease in summer; increase in autumn } \\
\text { and winter }\end{array}$ & $\begin{array}{l}\text { Decrease in flood season and Nov.; } \\
\text { increase in the other months }\end{array}$ \\
\hline \multirow[t]{2}{*}{ Variability } & $\begin{array}{l}\text { Average } \\
\text { flow }\end{array}$ & - & Increase & - & Decrease \\
\hline & $\begin{array}{l}\text { Monthly } \\
\text { distribution }\end{array}$ & - & $\begin{array}{l}\text { Increase in late spring and summer and } \\
\text { Oct.; decrease in the other months }\end{array}$ & $\begin{array}{l}\text { Increase in spring, summer and autumn; } \\
\text { decrease in winter }\end{array}$ & $\begin{array}{l}\text { Increase in summer and winter; } \\
\text { decrease in spring and autumn }\end{array}$ \\
\hline \multirow[t]{2}{*}{ Frequency } & Low flow & - & Decrease & Decrease & Increase \\
\hline & High flow & - & Decrease & Decrease & Decrease \\
\hline \multirow[t]{3}{*}{ Duration } & Low flow & - & Increase & Increase & Increase \\
\hline & Zero flow & - & Increase & Increase & Extremely increase \\
\hline & High flow & - & Increase & Increase & Increase \\
\hline \multirow[t]{3}{*}{ Timing } & $\begin{array}{l}\text { Average } \\
\text { flow }\end{array}$ & - & Increase & Increase & - \\
\hline & $\begin{array}{l}\text { Minimum } \\
\text { flow }\end{array}$ & - & Delayed & Advanced & Advanced \\
\hline & $\begin{array}{l}\text { Maximum } \\
\text { flow }\end{array}$ & - & Advanced & Advanced & Advanced \\
\hline \multirow[t]{2}{*}{$\begin{array}{l}\text { Temporal } \\
\text { slope }\end{array}$} & $\begin{array}{l}\text { Average } \\
\text { flow }\end{array}$ & - & - & Increase & - \\
\hline & $\begin{array}{l}\text { Monthly } \\
\text { distribution }\end{array}$ & - & $\begin{array}{l}\text { Increase in late spring and early summer; } \\
\text { decrease in the other months }\end{array}$ & $\begin{array}{l}\text { Decrease in autumn and winter; increase in } \\
\text { April (spring) and June (summer) }\end{array}$ & $\begin{array}{l}\text { Increase in spring, June and } \\
\text { autumn; decrease in July (summer) }\end{array}$ \\
\hline
\end{tabular}

Note: “-” means no significant variation.

increased in the spring, and the variation was defined as Late Summer Flow with Extremely Less Magnitude, Stability, Extremely More Intermittency by regulation (Late Summer Flow: EL-S-EI) (Table 5 and Fig. 8d).

\section{Discussion}

\subsection{Overall impact patterns by reservoirs and sluices}

The overall impacts of reservoirs and sluices in the Huai River Basin were similar to those reported in existing studies (Richter et al., 1996; Nilsson et al., 2005; Poff et al., 2007; Arthington, 2012; Zhang et al., 2010, 2013b; McManamay, 2014). These impacts caused the reduction of flow regime diversity and variability (i.e., high flow magnitudes, flow variability and frequency were decreased but low flow magnitudes and flow duration were increased) (Fig. 3). However, several distinct patterns were also detected, which were highly dependent on the characteristics of individual reservoirs and sluices and their actual capacities and regulation rules.

The flow regimes in Class 4 were altered most significantly because of the large regulation capacities (17.28-88.59\% of runoff) of the reservoirs in the headstream of northern tributaries. The regulation rules of reservoirs aimed to discharge water for residential needs and irrigation needs in the nonflood season and to store water for flood control in the flood season (Zhang et al., 2013b). This regulation category was quite similar to the "run-of-river reservoir" in the nonflood season and the "storage reservoir" in the flood season (after Poff and Hart 2002; McManamay, 2014). All stations in Class 2 were regulated by reservoirs in the headstream of southern tributaries with the regulation capacities from $20.89 \%$ to $130.83 \%$. These reservoirs were usually reserved as the emergency water sources for the upper and middle Huai River Basin. Thus, these reservoirs always aimed to store water for emergency needs (e.g., severe droughts and the specified paroxysmal water pollution incidents) and to discharge redundant waters before and in the early flood season to maintain safety (Zhang et al., 2013b). This reservoir belongs to the "run-of-river reservoir" category in the nonflood season. Most stations in Class 3 were the sluice-regulated stations in the middle and downstream of Shaying River. These sluices aimed to regulate peak flows in the flood season and to have slight effects on water storage (Zhang et al., 2013b). This category could be considered as the peak flow regulation sluice, which was different with the coarse rules of diversions and small dams in McManamay (2014). Although the regulation capacities by individual sluices were limited (from $0.26 \%$ to $2.21 \%$ ), the accumulation of upstream regulations also altered flow regimes (Table 1). Furthermore, the insignificant variation of flow regimes in Class 1 might be attributed by the slight regulation capacities (i.e., Suip, Bant and Bengb) or large flow magnitudes in the downstream of tributaries or Huai River (i.e., Xinc, Xix, Wangjb and Lutz). Three exceptions of reservoir-regulated stations were still in Class 1 (i.e., Banq, Zhaopt and Baigs), where the regulation obviously changed the indices (Fig. 3).

\subsection{Comparison of the regulations by reservoirs and sluices}

The regulations by reservoirs and sluices were quite different according to the flow classification, such as "run-of-river reservoir" in the nonflood season (Class 4 and Class 2), "storage reservoir" in the flood season (Class 4 ) and peak flow regulation sluice (Class 3 ). The categories of reservoir regulations were basically similar to the two coarse functional rules (i.e., "run-of-river" and "storage") reported in Poff and Hart (2002) and McManamay (2014), but the category of sluice regulation (peak flow regulation) was opposite to the diversion rules in McManamay (2014).

The degrees of flow alteration were basically consistent with the storage capacities of reservoirs and sluices. This finding could be further supported by the relationship between water storage and discharge in Zhang et al. (2013b). However, the impacted indices were different. The impacts of reservoir regulations were the greatest because of their large storage capacities and water storage in the nonflood season. The mainly impacted indices were the magnitudes and variability of low flows and channel drying. Comparatively, the impacts of sluice regulations were moderate, and the mainly impacted indices were the magnitudes of low flows 

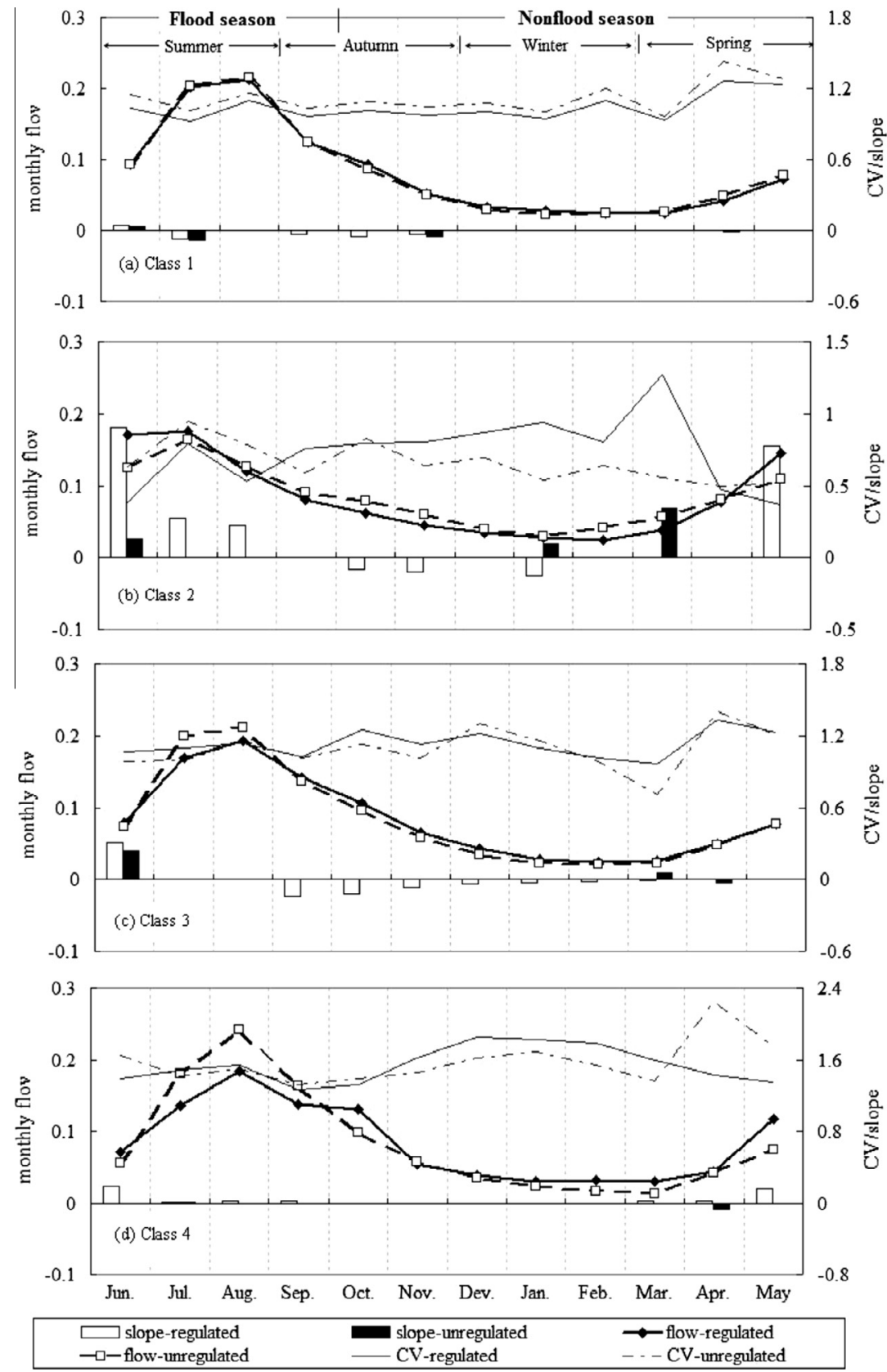

Fig. 8. The monthly distribution patterns of flow magnitudes and variabilities, and temporal slopes of monthly flow for each class.

and high flows and the variability, frequency and durations of low flows. At the least regulated stations, certain indices were still altered because of upstream regulations, such as high flow magnitudes, flow variability and low and high flow frequencies.

\subsection{Comparison with existing studies}

The direct classification of the value differences of flow indices between unregulated and regulated conditions was advantageous in capturing the diverse impacts of reservoirs and sluices. The flow regimes were obviously disturbed at $60 \%$ of the stations ( 18 out of 30 ), and three corresponding types of regulation rules existed in our study area. More variation characteristics were captured in comparison with the results of Zhang et al. (2012b) (only 7 out of 45 stations), although the same data source was used. The main reason is that the traditional comparison between the classifications for regulated and unregulated conditions was subjective, and the index values in each class would be changed obviously although the comprehensive characteristics of flow classes were the same in both conditions. For example, Zhang et al. (2012b) reported that the values of most indices in the same class changed. The most obviously changed indices were $\mathrm{LD}_{\mathrm{zr}}$, which increased by $46.7 \%, 36.2 \%$ and $278.2 \%$ in Class 1,2 and 5 , respectively, $\mathrm{LF}_{99}$ $(-60.9 \%)$ in Class $3, \mathrm{~S}_{\mathrm{M}}(29.5 \%)$ in Class 4 and $\mathrm{LF}_{99}(56.3 \%)$ in Class 5. The flow regime classes of unregulated stations (e.g., the Huangchuan Station) changed, although the values of flow regime indices were not altered at all. The obvious change of flow regimes in other stations by regulations would cause this results. Mackay et al. (2014) also found that the flow regime classes at more than half of the 113 gauges shifted to other classes without the alteration of dams or weirs in the southeast Queensland.

Furthermore, the flow classifications showed clearly different geospatial and climate patterns among flow classes (Kennard et al., 2010b), regardless of the regulated or unregulated 
conditions. These related factors included climate change, land use and geomorphological change, and urbanisation (McManamay et al., 2012; Mackay et al., 2014). However, the contributions of these factors to the regulated and unregulated classifications were different (Zhang et al., 2012b). Therefore, the differences between unregulated and regulated flow regimes were helpful in directly identifying the impact of reservoir and sluice regulations and efficiently avoiding the disturbance of other factors.

\section{Conclusions}

We combined the hierarchical classification and trend analysis to assess spatial and temporal flow regime alteration in the Huai River Basin. The classification procedure avoided the comparison of changes between the classifications of flow regimes with and without regulation. Moreover, flow regime indices extended to the existing by including the cumulative impact indices (i.e., temporal trends of long-term flow series).

The overall impact pattern of reservoirs and sluices on flow regimes in the Huai River Basin aimed to decrease the high flow magnitudes and increase the low flow magnitudes through time. This pattern also aimed to decrease flow variability and the high and low flow frequencies, while to increase the high and low flow durations. The impact of reservoirs was the most significant, followed by those of sluice regulations and the least regulated stations. The flow regime alterations of 30 stations were clustered into four classes, wherein the flow regimes in three classes (i.e., $60 \%$ stations) were altered obviously. These regulated stations were located in the upper and middle tributaries. Moreover, the dominant disturbing flow characteristics were monthly flow magnitude distributions and their variabilities, and the high and low flow frequencies.

The regulation rules of the water infrastructures should be revised to consider these dominant flow characteristics to avoid or reduce the ecological impacts in the downstreams. For example, the regulation rules of reservoirs and sluices in Class 4 should be modified to decrease low flow magnitude and occurrences, and increase high flow magnitude and frequency. The flow magnitude and the high and low flow frequencies should be increased, while flow variability and drying-up period should be decreased through regulations of reservoirs and sluices in Class 2 and Class 3. The scientific regulation principles for reservoirs or sluices should consider the natural flow regime paradigm, environmental flow strategies matched with flow classes and the harmony of "water quantity-water quality-ecosystem", instead of the socioeconomic oriented regulations (e.g., flooding control and water consumption).

\section{Acknowledgements}

This study was supported by the Natural Science Foundation of China (No. 41271005), the Key Project for the Strategic Science Plan in IGSNRR,CAS (No. 2012ZD003), the China Youth Innovation Promotion Association CAS (No. 2014041) and the Natural Science Foundation of China (Nos. 40901025, 51249010). The authors thank to the editor and the three anonymous reviewers for their useful comments and careful revisions that improved this manuscript.

\section{References}

Ahmet, K., Kadri, Y., Cengiz, O., 2006. Effects of Kilickaya Dam on concentration and load values of water quality constituents in Kelkit Stream in Turkey. J. Hydrol. 317 (1-2), 17-30.

Antoine, L., Sylvain, J., 2006. Using amap and ctc packages for huge clustering. R News 6, 58-60.
Arthington, A.H., Bunn, S.E., Poff, N.L., Naiman, R.J., 2006. The challenge of providing environmental flow rules to sustain river ecosystems. Ecol. Appl. 16 (4), 1311 1318.

Arthington, A.H., Naiman, R.J., Mcclain, M.E., Nilson, C., 2010. Preserving the biodiversity and ecological services of rivers: new challenges and research opportunities. Freshwater Biol. 55, 1-16.

Arthington, A.H., 2012. Environmental Flows: Saving Rivers in the Third Millennium. University of California Press, Berkeley, CA, 406pp.

Biemans, H., Haddeland, I., Kabat, P., Ludwig, F., Hutjes, R.W.A., Heinke, J., von Bloh, W., Gerten, D., 2011. Impact of reservoirs on river discharge and irrigation water supply during the 20th century. Water Resour. Res. 47, W03509. http://dx.doi. org/10.1029/2009WR008929.

Bunn, S.E., Arthington, A.H., 2002. Basic principles and ecological consequences of altered flow regimes for aquatic biodiversity. Environ. Manage. 30 (4), 492-507.

Chung, S.W., Ko, I.H., Kim, Y.K., 2008. Effect of reservoir flushing on downstream river water quality. Environ. Manage. 86 (1), 139-147.

Coghlan, A., 2011. A little book of $\mathrm{R}$ for multivariate analysis (release 0.1). Trust Sanger Institute, Cambridge, U.K. <https://little-book-of-r-for-multivariateanalysis.readthedocs.org/en/latest/>.

Costigan, K.H., Daniels, M.D., 2012. Damming the prairie: human alteration of Great Plains river regimes. J. Hydrol. 444-445, 90-99.

Goodman, L., Kruskal, W., 1954. Measures of associations for cross-validations. J. Am. Stat. Assoc., 732-764

Colwell, R.K., 1974. Predictability, constancy and contingency of periodic phenomena. Ecology 55, 1148-1153.

Graf, L.W., 2006. Downstream hydrologic and geomorphic effects of large dams on American rivers. Geomorphology 79, 336-360.

Helsel, D.R., Frans, L.M., 2006. Regional Kendall test for trend. Environ. Sci. Technol. 40 (13), 4066-4073.

Hirsh, R.M., Slack, J.R., 1984. A nonparametric trend test for seasonal data with serial dependence. Water Resour. Res. 20, 727-732.

Hirsch, R.M., Slack, J.R., Smith, R.A., 1982. Techniques of trend analysis for monthly water quality data. Water Resour. Res. 18 (1), 107-121.

Hu, W.W., Wang, G.X., Wei, D., Li, S.N., 2008. The influence of dams on ecohydrological conditions in the Huaihe River basin, China. Ecol. Eng. 33, 233-241.

Huang, S.L., Ferng, J.J., 1990. Applied land classification for surface water quality management: I. Watershed classification. J. Environ. Manage. 31, 107-126.

Hubert, L., Schultz, J., 1976. Quadratic assignment as a general data-analysis strategy. Brit. J. Math. Statist. Psychol., 190-241

Jolliffe, I.T., 1972. Discarding variables in a principal component analysis. I: artificial data. J. Roy. Stat. Soc.: Ser. C (Appl. Stat.) 21 (2), 160-173.

Kennard, M.J., Mackay, S.J., Pusey, B.J., Olden, J.D., Marsh, N., 2010a. Quantifying uncertainty in estimation of hydrologic metrics for ecohydrological studies. River Res. Appl. 26 (2), 137-156.

Kennard, M.J., Pusey, B.J., Olden, J.D., Machay, S.J., Stein, J.L., Marsh, N., 2010b. Classification of natural flow regimes in Australia to support environmental flow management. Freshwater Biol. 55, 171-193.

Lehner, B., Reidy, L.C.A., Revenga, C., Fekete, B., Vörösmarty, C.J., Crouzet, P., Döll, P. Endejan, M., Frenken, K., Magome, J., Nilsson, C., Robertson, J., Rödel, R., Sindorf, N., Wisser, D., 2011. High resolution mapping of the world's reservoirs and dams to assess the degree of global river regulation. Front. Ecol. Environ. 9, 494542.

Mackay, S.J., Arthington, A.H., James, C.S., 2014. Classification and comparison of natural and altered flow regimes to support an Australian trial of the Ecological Limits of Hydrologic Alteration (ELOHA) framework. Ecohydrology 7, 14851507.

McManamay, R.A., Orth, D.J., Dolloff, C.A., 2012. Revisiting the homogenization of dammed rivers in the southeastern US. J. Hydrol. 424, 217-237.

McManamay, R.A., 2014. Quantifying and generalizing hydrologic responses to dam regulation using a statistical modeling approach. J. Hydrol. 519 $1278-1296$.

Meila, M., 2007. Comparing clustering? An information based distance. J Multivariate Anal. 98, 873-895.

Monk, W.A., Wood, P.J., Hannah, D.M., Wilson, D.A., 2007. Selection of river flow indices for the assessment of hydroecological change. River Res. Appl. 23, 113122.

Nilsson, C., Reidy, C.A., Dynesius, M., Revenga, C., 2005. Fragmentation and flow regulation of the world's large river systems. Science 308, 405-408.

Olden, J.D., Poff, N.L., 2003. Redundancy and the choice of hydrologic indices for characterizing streamflow regimes. River Res. Appl. 19 (2), 101-121.

Petts, G.E., 1984. Impounded Rivers: Perspectives for Ecological Management. John Wiley, Baffins Lane, Chichester, UK.

Poff, N.L., Allan, J.D., Bain, M.B., Karr, J.R., Prestegaard, K.L., Richter, B.D., Sparks, R.E., Stromberg, J.C., 1997. The natural flow regime: a paradigm for river conservation and restoration. Bioscience 47, 769-784.

Poff, N.L., Hart, D.D., 2002. How dams vary and why it matters for the emerging science of dam removal. Bioscience 52, 660-668.

Poff, N.L., Olden, J.D., Merritt, D., Pepin, D., 2007. Homogenization of regional river dynamics by dams and global biodiversity implications. Proc. Natl. Acad. Sci. 104, 5732-5737.

Postel, S.L., 1998. Water for food production: will there be enough in 2025? Bioscience 48, 629-637.

Postel, S., Richter, B., 2003. Rivers for Life: Managing Water for People and Nature Island Press, Washington, D.C. 
R Development Core Team, 2010. R: A language and environment for statistica computing. R Foundation for Statistical Computing, Vienna, Austria, ISBN 3900051-07-0. <http://www.R-project.org>.

Richter, B.D., Baumgartner, J.V., Powell, J., Braun, D.P., 1996. A method for assessing hydrologic alteration within ecosystems. Conserv. Biol. 10 (4), 1163-1174.

Snelder, H.T., Biggs, F.B., 2002. Multiscale river environment classification for water resources management. J. Am. Water Resour. Assoc. 38 (5), 1225-1239.

Snelder, T.H., Lamouroux, N., Leathwick, J.R., Pella, H., Sauquet, E., Shankar, U., 2009. Predictive mapping of the natural flow regimes of France. J. Hydrol. 373, 56-67.

Vörösmarty, C.J., McIntyre, P.B., Gessner, M.O., Dudgeon, D., Prusevich, A., Green, P. Glidden, S., Bunn, S.E., Sullivan, C.A., Liermann, C.R., Davies, P.M., 2010. Global threats to human water security and river biodiversity. Nature 467, 555-561.

Wang, G.S., Xia, J., 2010. Improvement of SWAT2000 modelling to assess the impac of dams and sluices on streamflow in the Huai River basin of China. Hydrol. Process. 24 (11), 1455-1471.

Ward, J., 1963. Hierarchical grouping to optimize an objective function. J. Am. Water Resour. Assoc. 58, 236-244.

World Commission on Dams (WCD), 2000. Dams and Development: A New Framework for Decision-Making. Earthscan Publications, London.

Wu, J.G., Huang, J.H., Han, X.G., Xie, Z.Q., Gao, X.M., 2003. Three-Gorge damexperiment in habitat fragmentation? Science 300, 1239-1240.

Xia, J., Zhang, Y.Y., Zhao, C.S., Stuart, E.B., 2014. Bioindicator assessment framework of river ecosystem health and the detection of factors influencing the health of the Huai River Basin, China. J. Hydrol. Eng. 19 (8), 481-486.

Zhang, Q., Xu, C.Y., Chen, X.H., Lu, X.X., 2012a. Abrupt changes in the discharge and sediment load of the Pearl River, China. Hydrol. Process. 26 (10), 1495-1508.
Zhang, Q., Singh, V.P., Xu, C.Y., Chen, X.H., 2013a. Abrupt behaviors of streamflow and sediment load variations of the Yangtze River basin, China. Hydrol. Process. 27 (3), 444-452.

Zhang, Q., Xiao, M.Z., Liu, C.L., Singh, V.P., 2014. Reservoir-induced hydrological alterations and ecological instream flow in the East River, the Pearl River basin, China. Stochas. Environ. Res. Risk Assess. 28, 2119-2131.

Zhang, Y.Y., Xia, J., Liang, T., Shao, Q.X., 2010. Impact of water projects on river flow regime and water quality in Huai River Basin. Water Resour. Manage 24, 889908

Zhang, Y.Y., Shao, Q.X., Xia, J., Bunn, S.E., Zuo, Q.T., 2011. Changes of flow regimes and precipitation in Huai River Basin in the last half century. Hydrol. Process. $25,246-257$.

Zhang, Y.Y., Arthington, A.H., Bunn, S.E., Mackay, S., Xia, J., Kennard, M., 2012b. Classification of flow regimes for environmental flow assessment in regulated rivers: the Huai river basin, China. River Res. Appl. 28, 989-1005.

Zhang, Y.Y., Xia, J., Shao, Q.X., Zhai, X.Y., 2013b. Water quantity and quality simulation by improved SWAT in highly regulated Huai River Basin of China. Stochas. Environ. Res. Risk Assess. 27, 11-27.

Zhang Y.Y She, D.X. Xia, J., Zhai, XY. Zuo, OT, 2015. Causal analysis on the specified paroxysmal water pollution incidents in Huai River Basin. Environ. Eng. Manage J. 14 (1), 139-151.

Zhou, Y., Zhang, Q., Singh, V.P., 2014. Fractal-based evaluation of the effect of water reservoirs on hydrological processes: the dams in the Yangtze River as a case study. Stochas. Environ. Res. Risk Assess. 28, 263-279. 